\title{
Sustainable Competitive Advantage of Indonesia's Creative Economics: Fashion Sub-Sector
}

\author{
Afni Regita Cahyani Muis, Ali Musa Harahap, Fadhlan Nur Hakiem \\ University of Darussalam Gontor, Indonesia
}

\begin{abstract}
This research has identified the government's strategies to encourage creative fashion industries in Indonesia with its cultural branding and the applicability of sustainable competitive advantage as a concept to maintain competitiveness. This research employed a qualitative research method based on primary data, obtained from in-depth interviews at the Creative Economy Agency, the Indonesian Ministry of Trade and, the Indonesian Ministry of Industry, and the Central Statistics Agency. In analyzing the data, this research categorizes the reports and journals of the government's endeavor result. It then reduced the data by creating a discussion scheme and writing the core of each discussion component. Data is triangulated to compare the results of interviews with research objects and documents. The research found that the following are crucial strategies to empower sustainable competitive advantage of the creative economy in Indonesia's fashion subsector: Developing Priority Industry Clusters, Research and Development, Indonesia Trend Forecasting, Innovative and Creativity through Nusantara Collaboration, Modest Fashion, Intellectual Property Rights, and Economic Partnership Agreement.
\end{abstract}

Keywords: Creative Economics, Sustainable Competitive Advantage, Fashion

\section{INTRODUCTION}

This is an open access article under the CC-BY-NC license.

Development strategies should accommodate cultural, economic, social, and technological shifts that are speedily changing our world, this research suggested. 21 st century is the recognition of creativity and human talent as a powerful tool to advance development growth. In economic global turmoil particularly, the creative economy is one of the sectors which has a positive way for a state to deal with it. Also, it is becoming a soft power for a state as a result of optimizing national competitiveness. For instance, Japan and England are evidence to allow human skills in contributing to their economy by succeeding in the creative industry. Creative economy subsectors in England composed of advertising, architecture, arts and antique market, arts and crafts, design, fashion, cinema and video, leisure software, music, performing arts, publishing, computer and software services, radio, and television. England was pushed Gross Value Added (GVA) by 37.5\% in 2014 until 2018 in comparison with other sectors which only increased by $18.2 \%$. Added, Information Technology, Software, and Computer Services is a creative economic subsector with the top rates in $43.5 \%$ of the total GVA. The subsector is followed by design products, such as graphic and fashion design. (DCMS, 2016). Likewise, in Japan, it enhances competitive advantage in the creative industry by collaborating "local wisdom' and modernization. The existence is based on Japan"s intention to advance the innovation continually. The creative economy in Japan is under the

Corresponding author

afniregita@unida.gontor.ac.id

DOI: https://doi.org/10.31098/tsdr.v1i2.12

Research Synergy Foundation 
patronages of the Ministry of Economy, Trade, and Industry by introducing „Cool Japan' strategy as a soft power in advertising culturally creative products such as manga and animation. Moreover, Japan"s creative industries are mostly driven by small and medium-sized enterprises.

The preferred creative economic sub-sectors among others are Fashion, Culinary, and Crafts which have high supply and demand in the global market. By choice, fashion is the most valuable in international trade which ultimately reached high rates for export value. The states with high-quality fashion will accept a positive impact on business field growth, mainly for Small and Medium Enterprises (SMEs). Creative fashion is increasingly known by the public due to its characteristics and diversities. Besides human primary needs, fashion creates a sense of identity, this research suggests. Along with its development, fashion and politics are also completely linked. For instance, Charles II of Britain recognized a new fashion of suit jacket as a calculated strategy to ruin French influence on Britain. The United Kingdom"s influence spread out all around the world following the situation. Additionally, Peng Liyuan (Xi Jinping"s wife) of China engages headlines for her fashion matter on Chinese brand. Her "taste" communicates the nationalist confidence by promoting national consumption in China"s creative industries. The fashion world extends to be a forceful social, political, and cultural drive because fashion consciously and unconsciously affects the way people dress. Thus, the relation between fashion and soft power stays intrinsic and lasting (British Council, 2016).

Mainly to the benefit of the developing states, economic orientation can be shifted to the creative economy by empowering its huge resources; human resources and heritage. Taking Indonesia as the unit analysis of the research, the state is seen to have cultural and natural wealth from Sumatera until Papua. It creates a variety of "locals" as the material for the creative industry. In the year of 2015, Badan Ekonomi Kreatif (BEKRAF) has declared sixteen sub-sectors of creative economics. They are Culinary, Crafts, Fashion, Movies, Video, and Animation; Photography, Apps and Game Development, Architecture, Interior Design, Visual Communication Design, Product Design, Publishing, and Advertising, Performing Arts, Fine Arts, Television and Radio.

This research argues that the strongest export value of Indonesia's creative economy is the fact that it is made by Indonesia's culture which is not owned by other states. As the state which has cultural diversity, Indonesia has arranged the trend for promoting its identity and cultural brandings, such as batik and tenun. The significance of fashion in export value shows that fashion is a preferable export sector that has a competitive advantage in the global market.

Therefore, this research sees its importance to describe the extent of sustainable competitive advantage in maintaining the competitiveness of Indonesian creative fashion.

\section{LITERATURE REVIEW}

Indonesia's creative fashion design may build the nation's image to the world. As the meeting of countries discussing the progress of world security in New York in 2019 is concerned, Batik is used by the delegates from the United States, Germany, Gading Beach, France, Peru, the Dominican Republic, China, and even Antonio Guterres as United Nations Secretary-General.

This meeting was dubbed Batik Diplomacy as a form of respect to Indonesia (Kompas International, 2019). The use of Batik as a symbol of the Indonesian state has been implemented since the era of President Soeharto. At that time, he actively used Batik in important meetings of the country, some of them were the UN conference, the APEC Summit Meeting, a meeting with Bill 
Clinton and Ronald Reagen. President Soeharto's efforts in introducing Batik to the world also indicated by the fact that Batik was given as a souvenir to the States" guests (Cendana News, 2018). Creative fashion plays a role in increasing or strengthening Indonesia's soft power.

Soft power describes the ability to get what wanted through attraction rather than coercion or payments. The development and success of the Indonesian government in encouraging creative fashion will obtain admiration and imitation of other countries on the steps taken by Indonesia.

When other countries see Indonesia as a reference for their creative inspiration, this indicates the success of brilliance as a form of Indonesia"s soft power. If this is successful, Indonesia may have the capacity to influence the behavior of other countries without coercion.

Over the decades, Indonesia has been in a period of economic transition, becoming a manufacturing alternative in the process. In economic terms, Indonesia's market-oriented reforms have brought economic transformation, raising millions of people out of poverty (Suharyadi et. al, 2010). The country's economic success attracted many foreign investors and continues to do so (Cahyono, 2013). Particularly with the fashion world, some examples of multinational companies that became successful in Indonesia include Ni Luh Djelantik, Nike, and others (Djohan \& Brahmana, 2017; Sampurna, 2019). What makes Indonesia attractive to investors is that its reforms and economic growth made the country a consumer; including massive consumers who have begun to demand more goods in fashion. The country's exports increased amounted to US $\$ 4,734$ million in 2000 or at an average growth rate of about 17 percent; this benefit resulted from low labor cost, the increase in garment exports, availability of skilled labor, the government supports through a series of conducive policy and Indonesia's joint venture (Shihab \& Jain, 2004).

With all these economic potentials in Indonesia, other economic factors are needed to be investigated, and how to incorporate strategies. Along with the growth of the Indonesian economy, the fashion industry has grown simultaneously. Since the reformation period of Indonesia's democracy, there has been a serious drive to promote the country. For instance, through technology transfer at the micro-level in the Indonesian textile and garment, the economy increased significantly. In efforts to increase production capability, Indonesian textile and garment manufacturers established strategic alliances with their Japanese counterparts, and the alliances had become the most important channel of production (Tambunan, 2011). Similarly, that business linkages with foreign companies is a very important channel for the transfer of technology within the industry, especially for the consumer. However, technology transfer in the textile industry was limited to improvements in production capability. It is important, more activities that may help local firms improve their capabilities, pre-investment, project implementation, and technical changes in production may be implemented.

However, despite this growth in the fashion industry, Shihab and Jain (2004) argued that there are still many questions that need answers concerning this rapidly expanding and culturally complex economy of Indonesia's fashion industry. Some of the unanswered questions pointed out include: What is the current fashion context in Indonesia in terms of preparedness? What lessons must local firms operating in Indonesia learn about current fashion strategies? These questions lead to another image to portray Indonesian capability in the fashion industry. Some perspectives are determined to see its possibilities in analyzing current Indonesia's situation in the fashion industry. They are sustainable competitive advantages and a creative economy. 
The term competitive advantage simply describes the advantage a company has over other companies, which compete in the same market (Burn, 2008). Competitive advantages, therefore, are the attributes that a given company can deliver over its competitors in terms of assets. The term appropriately has the word advantage in it as it gives a company that possesses it an advantage in the market place, but it does not guarantee success. The reason for its sustainability is because of the unpredictability and the instability of the environment a given company operates. Therefore, it is important to employ sustainable considers the protection of such attributes and resources have to offer over some usually undefined period into the future for the organization to maintain its competitiveness (Chaharbaghi \& Lynch, 1999).

Secondly, the creative economy emulates the creative type whose decisions to live or survive are no longer based on the availability but the qualities of place, the abundance of talent, technology, and other intangible qualities (Rodrigues, 2018). The creative economy concept is a holistic and multidisciplinary approach, dealing with the interface between economy, culture, technology, concentrated on the predominance of products and services bearing creative content, cultural value, and market objectives. The creative economy is distinguished from other concepts due to its uniqueness. It accepts the value of originality, collective works, and intangible aspects which is based on culture and diversity (Edna Duisenberg, 2018). In obtaining its optimum results, this creative economy should be implemented and supported by at least three categories of groups; workforce, industries, and communities (Schmidt, 2008). For instance, workers are to use their creativity to create something new and valuable. The creative process is to be implemented to find and solve problems. Creative industries are to use creativity to develop creative products which in turn are sold for profit and engage in a creative process to develop or produce something new, which has an economic value in the absence of tangible assets. The creative economy is dependent on talented individuals and the community. Hence, the community should capitalize their talents for the economy to sustain despite its incapacities from tangible assets.

This research has filled up the gap in the literature at least from two aspects. First, the research analyzes the difference form from the manufactured fashion industries in Indonesia's experience. Second, the research is analyzing the situation from the perspective of international economy and politics, taking into account the Indonesia's potential. Taking into account the Shihab and Jain's research in 2014, this research has answered their questions about the current fashion context of Indonesia in terms of preparedness and what lessons must local firms operating to be in line with current fashion industries" strategies. This research also has to lead to portraying Indonesia's capability in the fashion industry.

\section{RESEARCH METHOD}

This research employs a qualitative research method. Data sources used in this research are primary data, obtained from interviews at the Creative Economy Agency, the Indonesian Ministry of Trade and, the Indonesian Ministry of Industry, and the Central Statistics Agency. It also conducted library studies by facilitating books and journals at the Central Library of Gadjah Mada University, the National Library of the Republic of Indonesia, and the Republic of Indonesia's Ministry of Trade Library. The technique interview analysis as a result of the interview that is transcript. It also analyzed the report and journal of government's endeavor result. Then, it reduced the data by creating a discussion scheme and writing the core of each discussion component. Data 
is triangulated to compare the results of interviews with research objects and documents. This is useful for tracking the validity of research analysis with the existing data. It ended with concluding by explaining the causality of the research. The research was conducted in the year 2017 and the year 2020.

\section{FINDINGS AND DISCUSSION}

The creative economy has contributed positively to international trade when global dilemma impacted Indonesia in the year of 2008 to 2009. It is due to overall Indonesia's export value, the creative economy has improved. The significance of the creative economy towards Indonesia's economic development responded by the Indonesian government through Presidential Instruction in the year of 2009. The creative economy's result in 2014 to 2015 was presented at $9.71 \%$ when non-oil and gas decreased. The strengthened of creative economy export by sub-sector was dominated by fashion by $56 \%$ (BEKRAF, 2017). It covers clothes, shoes, jewelry, and a bag (Andy Ruswar, 2017). The exporters predominantly come from Java Island, mainly East Java, then Sumatera and Bali with the top five export destination countries, such as United States, Japan, Taiwan, Switzerland, and Germany (BEKRAF, 2017).

Fashion is the combination of clothing styles that constructs creation. It is categorized as an element of a creative economy because it tends to be a hand-made product (combining with technology) with characteristics in raw materials and designs. Fashion also has been an interpretation of culture, geography, climate, and personal taste of historical perspective. The designers are inspired not limited to creativity, but sustainability and economic reason as well (Stefko and Steffek, 2018). Creative fashion is almost similar to a slow fashion perspective. The general factor is production cost, both are mainly local source and tend to earn higher prices.

Then, the designers sell small collections with variable costs. In quality, there is education about clothing, its origin, and material used. In service, it shapes a key of competitive advantage and the designers may raise the competition with quick fashion retail. In responding to the trend, both do not rapidly change fashion trends. On the contrary, the garment and textile are manufactured industry. They are in mass-production businesses that prioritize market volume and modify trend design and produced in large quantities. To illustrate the situation, Indonesia's Fashion Industry Value Chain Table below explains it in detail.

Table 1. Fashion Industry Value Chain

\begin{tabular}{|c|c|c|c|c|}
\hline $\begin{array}{c}\text { Creation } \\
\text { (creative idea- } \\
\text { product's pattern) }\end{array}$ & $\begin{array}{c}\text { Production } \\
\text { (Cutting-shaping- } \\
\text { finishing) }\end{array}$ & $\begin{array}{c}\text { Commercialization on } \\
\text { (promote, } \\
\text { brochure, media, } \\
\text { exhibition) }\end{array}$ & Distribution & \multirow{2}{*}{$\begin{array}{c}\text { Domestic and } \\
\text { International } \\
\text { Market }\end{array}$} \\
\hline Supporting & Supporting & Supporting & $\begin{array}{c}\text { Distribution } \\
\text { channel }\end{array}$ & \\
\hline 1. Trend and & 1. Leather industry & 1. Festival/show & \begin{tabular}{|l|} 
Gallery Shop \\
Traditional
\end{tabular} & \\
\hline World Mark & $\begin{array}{l}\text { 2. The industry } \\
\text { button, }\end{array}$ & of 2. Government & $\begin{array}{l}\text { and modern } \\
\text { market Distro }\end{array}$ & \\
\hline
\end{tabular}




\begin{tabular}{|c|c|c|c|}
\hline 2. Customers & stain, and others & 3. Fashion & $\begin{array}{l}\text { Factory Outlet } \\
\text { Wholesale }\end{array}$ \\
\hline preferences & related & Association & \\
\hline 3. Social & 3. Fiber industry & 4. Media & \\
\hline research, & 4. Tenun industry & 5. Publisher & \\
\hline social and & 5. Convection, & & \\
\hline $\begin{array}{l}\text { cultural, and } \\
\text { history }\end{array}$ & border, and sewing & & \\
\hline
\end{tabular}

Source: Ministry of Trade of Indonesia

The fashion industry value chain has exercised a creative economy to global retail. The chain is started from designers who become a creator for researching, choosing, and designing to evolve the creation. Production is a process of how the pattern of fashion managed by the industry. Then, commercialization is used for marketing the products to be disseminated to the wider community. Lastly, the distribution channel in the market place that can be found on the internet or in any direct market.

Indonesia may also gain market share by incorporating its capacities. First, culturally Indonesia has more than 300 ethnic groups with more than 700 diversities in languages and 13.644 islands. It reveals that Indonesia's cultural diversity scattered in diverse provinces which appear "local wisdom" as an abundant asset for the content creator, mainly for fashion designers "s creation. Second, from the economic point of view, fashion has been a significant contribution to Indonesia's economic growth. For instance, in 2014, Indonesia's Ministry of Industry recorded that it accounted for IDR 181.5 trillion of national GDP or $28.29 \%$ of the total contribution of the economy. It also captivates the most workforce that is 3.838 .756 people of 1.107 .956 business units. Hence, the ability to meet supply and demand, fashion subsector is the biggest contributor to Indonesia's export growth, amounted to $9.51 \%$. Third, as the human resources are concerned, the number of Indonesian fashion designers who have a good reputation internationally such as Tex Saverio and Sebastian Gunawan whose design is used by Hollywood celebrities also added value to it. The workers in the production sector also play a crucial role, functioning in screen printing and tailoring (Kemendag, 2017).

Indonesia's fashion product exports in the period 2010-2015 showed significance with an increasing trend. The growth rate was 5.18\%. The biggest increase in export growth occurred in 2011 by $20.65 \%$, while the achievement of the largest export value was US\$10,895.2 million in 2015. In 2010 and 2011, it reached US \$ 8,584.3 million and US \$ 10,356.9 million. This number represents a contribution of $63.55 \%$ and $66.21 \%$ to the total export value of the creative economy sector.

To become a newly developed industrial country, the Indonesian industrial sector must have several criteria, including the high contribution to the national economy; SME's balanced ability with large industries; strong industrial service that supports international competitiveness; and liberalization. The target of the creative industries' development is aimed at increasing exports of industrial products and strengthening the national economy connectivity. In line with the stages of 81 
achieving industrial development in the year of 2015-2019 period (5 years), it is necessary to encourage the development and utilization of creativity and innovation by providing space, territory, and infrastructure for the development of creativity and innovation; development of creative industry centers, technology and design training, facilitation of protection of intellectual property rights; and promotion or marketing of creative industry products.

The implementation to empower Indonesia's sustainability in the competition is as follows. Firstly, the fashion industry has become one of the roadmaps for developing Priority Industry Clusters. The performance of the National Industrial Policy is implemented on the synergy of the central government and regional governments by developing 35 priority industrial clusters in various regions and selected based on international competitiveness and the potential of the Indonesian people. Then, it determines the core competencies of the regional industries that become the superiority of the region, where the central government helped build its development so that the region has competitiveness.

Secondly, as the Research and Development (R\&D) is concerned, The significance of research in the development of fashion products is to become a trend-setter in the design field, a field that touches people's lifestyles directly (lifestyle), so that the accuracy of fashion producers in understanding lifestyle changes in society is needed. Knowledge of changing life patterns is needed by producers" commitment to be in line with the expectation of the global market. It is because, by creating trends, it is not only examining changes in design elements, such as color, texture, and volume but also examining people's mindsets by looking to the impact of various general aspects, such as social, political, economic, technological progress, even environmental issues. Activities of export must be also oriented with the familiarity of destination's country. For instance, the European market has a criterion that is a simple and elegant fashion color taste. American has a diversity of motives, but simple shape. African is colorful, and so on. The standardization elaborates the local culture with the destination"s country. R\&D activities for creative fashion will be output for Indonesia Trend Forecasting, which is a reference for academics to harmonize education about fashion going forward. The role of academies is needed to form a generation that understands fashion as a subsector that drives creativity or shapes generations as creative actors. Education for creative actors is an effort to foster capacity building through schools and tertiary institutions. Innovative and creative activities through the Nusantara Collaboration are also very positive in building the potential of regions, because the regions selected in IKKON then get the latest exposure and added value, among others in the field of marketing and promotion. This activity is carried out by actors who are qualified in the creative economy. Likewise for modest or Muslim fashion that is not limited to Muslims and the existence of Indonesia in the fashion modest scene is already well known in the international fashion industry so that Indonesia is capable of becoming the world's modest fashion barometer.

Thirdly, as the Indonesia Trend Forecasting (ITF) is concerned, the Creative Economy Agency in collaboration with Indonesia Trend Forecasting (ITF) are to create contemporary fashion trends. It started by compiling decoding (design translation) in five design fields, one of which is fashion design. The decoding was arranged in collaboration with various associations and educational institutions in the field of fashion. The decoding results are then directed to meet the needs of designers, producers, SMEs, to read the market mindset and be able to interpret it. 
Fourth, as the SMEs is concerned, the government through BEKRAF integrates with the Regional National Crafts Council (DEKRANAS) to facilitate research related to the development of batik, weaving, and improving the quality of fashion designs. This is integrated with the creative economy education program, namely Inovatif dan Kreatif melalui Kolaborasi Nusantara (IKKON) in encouraging regions to develop their existing potential. This program is integrated with the sustainability of the central government and local government programs. IKKON is intended to produce ethical sharing benefits and fair trade of both parties. This activity is carried out every year since 2016 under the auspices of the Creative Economy Agency. IKKON participants are a group of creative economic actors with various design sub- backgrounds. They interact, explore, and collaborate with local creative potentials to create added value without losing local characteristics so that they encourage and help develop the potential of the creative economy in the region.

Fifth, as the Modest fashion or Muslim fashion is concerned, the Indonesian fashion now is oriented towards Muslim fashion which has the identity of clothing covering the genitals (not only hijab fashion). Mapping fashion is implemented with a style that is Indonesian in-character. The Indonesian population is dominated by Muslims. Knowledge of Muslim fashion critical, so that the appeal may popular, both on a national and international scale. The realization plan as a barometer of Indonesian Muslim fashion is based on the daily lifestyle of the Indonesian people, which is about twenty million residents wearing Muslim clothing and hijab. From 750,000 SME business units in Indonesia, among them are engaged in the Muslim fashion sector by $30 \%$ with an average growth of $7 \%$ per year. Another factor driving this growth is the Muslim or hijab communities in Indonesia. This is supported by various performances of world Muslim fashion activities. The development of Muslim fashion has been transformed into modest fashion, which is intended not only for Muslim societies but is aimed at all people with clothing orientation covering genitalia. Muslim fashion began to touch the lifestyle of Western society, related in appearance, both people in Europe and North America.

Sixth, as the Intellectual Property Rights (IPR) is concerned, it becomes a significant foundation in protecting fashion products that are subject to the continual development of creativity and innovation. Fashion products labeled IPR will protect the products created by creative and skilled actors to get exclusive rights. Politically, they represent Indonesia, so that they are not claimed by other countries.

Seventh, as the Economic Partnership Agreement is concerned, through FTA and CEPA with countries that are potential for Indonesian fashion exports, they are crucial as the efforts to negotiate to finalize tariffs and non-tariff barriers. Member countries involved in FTAs are allowed to increase trade between members. It is facilitated by removing trade barriers because the FTA agenda includes an agreement to impose a $0 \%$ tariff on all imports from member countries. Then, to create a capacity building, student exchange between Indonesia and Australia in fashion design should also be implemented. So, it has a positive impact on efforts to expand the export market and the competitiveness of Indonesian fashion products in the global market. As stated earlier, the creative economy in the fashion industry has a positive contribution to the Indonesian international trade. The growth has reached a level of $9 \%$ from the creative fashion industries as previously stated. This illustrates that the creative fashion has a very significant contribution. According to the Indonesian Creative Economy Agency (BEKRAF), fashion is the second-largest 
contributor to gross domestic income (GDP) in the creative industry category and is the highest contributor to GDP in terms of exports (BEKRAF, 2017).

This research has several limitations. First, the process of data identification from the Central Statistics Agency is difficult such as which fashion comes from the creative industry and which fashion comes from the manufacturing industry. It is also recognized by the Ministry of Trade for identifying creative fashion with the Harmonized System Code in international trade activities. The limitation of identifying this then becomes a recommendation for how the government upstream and downstream towards managing the data of the creative and manufacturing fashion industry. Furthermore, data from the Ministry of Industry that sets priority clusters is only aimed at regions that are ready to compete.

\section{CONCLUSION}

Indonesia has a soft power to build a national image that the development and success of the Indonesian government in encouraging creative fashion will obtain admiration and imitation of other countries on the steps taken by Indonesia. Then, the fashion subsector has a competitive advantage value among sixteen other subsectors, because Indonesia empowers national values that are not possessed by other nations. For instance, Indonesia's cultural heritage, history, and geographical characteristics. This makes the Indonesian fashion industry becomes a competitor in global trade. The impact of the development in information technology also stimulates changes in people's preferences that are dynamic, critical of their diverse, and rapidly evolving needs. National competitiveness that is maintained requires industry capacity to innovate and to be creative to create sustainable competitive advantage.

The dynamics of Indonesia's fashion industry continues to develop, creates trends, and shapes a variety of creations in contemporary time. It has an impact on Indonesian fashion competitiveness products to compete in global trade. To encourage a sustainable competitive advantage in the creative economy fashion subsector, at least there are seven points in which Indonesia is going through; developing Priority Industry Clusters; R\&D; Indonesia Trend Forecasting; Muslim or Modest Fashion; Intellectual Property Right; and Economic Partnership Agreement. Indonesia should strive the competitiveness by running the relevant strategies to encourage sustainable competitive advantage that oriented to global trade. The inter-helix ecosystem should also be synergized to develop a creative economy that has a sustainable competitive advantage which drives economic growth. The sustainable competitive advantage of Indonesia's creative fashion with export-oriented values, of course, must be supported by the development of international markets. Reducing trade barriers and creating a capacity building with an established country towards the world fashion industry may be a satisfactory step to start from.

\section{ACKNOWLEDGEMENT}

The authors would like to thank the University of Darussalam Gontor, especially to Dr. KH. Ahmad Hidayatullah Zarkasyi, M.A. as the Dean of Faculty of Humanities, Dr. Mohammad Latief, M.A. as the Head of Department of International Relations for his gentle and helpful instructions, Dr. Nur Hadi Ihsan, MIRKH. as a Counselor of the University of Darussalam Gontor for Girls (UNIDA Gontor Putri) and Ahmad Fajaruddin as a Chief of General and Financial Administration Bureau of 
UNIDA Gontor for Girls. The authors would also like to thank Badan Ekonomi Kreatif, Ministry of Trade, and the Ministry of Industry for their cooperation in this research.

\section{REFERENCES}

Burns, P. 2008. "Corporate Entrepreneurship: Building the Entrepreneurial Organization"', New York: Palgrave Macmillan.

Cahyono, Kurniawan Dedy."Determinan Foreign Direct Investment (FDI) Dan Pengaruhnya Terhadap Produk Domestik Bruto (PDB) Di Indonesia". Bogor Agricultural University,

Chaharbaghi, K, Lynch, R. 1999. „"Sustainable competitive advantage: towards a dynamic resourcebased strategy"'.' East London Business School: MCB University Press.

Rodrigues, Abby Irene T. 2018. "Rethinking The Creative Economy: The Diverse Economies Of Artists And Artisans In Rural Massachusetts". University of Massachusetts Amherst.

Schmidt, Brad Robert. "An analysis of the creative economy in rural Midwestern communities".

Iowa State University.

Roesfitawati. Direktorat Pengembangan Ekspor Nasional Kementerian Perdagangan RI on October 2017.

Ruswar, Andy. Kasubdit Pemasaran Luar Negeri Deputi Pemasaran Badan Ekonomi Kreatif on October 26.

Djohan, Nita Sofiani, Ritzky K.Brahmana, "Willingness to Pay Premium for Luxurious Fashion". Brands in Indonesia: Is It Love"', International Journal of Innovation, Management and Technology, Vol. 8, No. 5.

Jain, Sudhir K., Muchsin Shihab. 2004. "'The Preparedness Of The Indonesian Garment Exporters In The Post-MFA Scenario An Analysis From The Survey, Gadjah Mada International Journal of Business, Vol. 6, No. 3, 2004.

Sampurna, Rizki Hegia. "A Critical Review Of The Impact Of Multinational Corporations (MNCS) On Indonesian Economy"', JISPO, Vol. 9.

Suryahadi, Asep, Athia Yumna, Umbu Reku Raya, Deswanto Marbun. 2010."' Review of Government's Poverty Reduction Strategies, Policies, and Programs in Indonesia". The SMERU Research Institute.

Stefko, Robert, Vladimira Steffek. 2018. "Key Issues in Slow Fashion: Current Challenges and Future Perspectives". MDPI.

Tambunan, Tulus. 2011."Do multinational companies transfer technology to local small and medium-sized enterprises? The case of the Tegal metalworking industry cluster in Indonesia".

Amsterdam University Press.

Kakluchi, Emiko., Takeuchi, Kiyoshi. 2014. "Creative Industries: Reality and Potential in Japan”. Tokyo: National Graduate Institute for Policy Studies.

Badan Ekonomi Kreatif dan Badan Pusat Statistik. 2017. "Data Statistik dan Hasil Survei Ekonomi Kreatif", Jakarta: Badan Ekonomi Kreatif and Badan Pusat Statistik.

Department for Culture, Media and Sport. 2016. “Creative Industries Economic Estimates”,United Kingdom.

Direktorat Pengembangan Produk Ekspor,"Fact Sheet : Industri Fesyen Indonesia”, Jakarta : Kementerian Perdagangan RI. 
Dirjen Pengembangan Ekspor Nasional. 2017.“Indonesian Export of Fashion to World By Country of Origin, 2012 to June 2017", Kementerian Perdagangan RI.

Itau Cultural, Garimpo de Soluces. 2008. "Creative Economy: As a Development Strategy: A View of Developing Countries". Sao Paulo: Itau Cultural.

Nye, Jr, J.S. 2004. "Soft power: the means to success in world politics", New York: Public Affairs.

OECD. 2018. "The Value of Culture and the Creative Industries in Local Development".

OECD Trento Centre for Local Development. 2018. "Summer Academy on Cultural and Creative Industries and Local Development". Italy: OECD.

Akhmad Sekhu. 2018. "Upaya Presiden Soeharto Kenalkan Batik pada Dunia". Accessed in https://www.cendananews.com/2018/10/upaya-presiden-soeharto-kenalkan-batik-padadunia.html on February 92020.

Ardi Priyatno Utomo. 2019. "Unik, Delegasi Dewan Keamanan PBB Pakai Batik dan Tenun Saat Bersidang". Accesed in https://internasional.kompas.com/read/2019/05/08/05584981/unik- delegasi-dewankeamanan-pbb-pakai-batik-dan-tenun-saat-

bersidang?utm_source=Facebook\&utm_medium=Refferal\&utm_campaign=Sticky_Mobile on February 92020.

Badan Ekonomi Kreatif. 2015.“Potensi Industri Kreatif dalam Promosi Diplomasi Ekonomi”. Accessed https://diplomasiekonomi.kemlu.go.id/images/capbuilddiplomat/Paparan\%20BEKRAF.pdf on August 222017.

BBC. 2019. "Diplomasi Batik' Indonesia sebagai Presiden DK PBB dan Perdamaian Palestina" Acessed in https://www.bbc.com/indonesia/indonesia-48199268 on February 92020.

British Council. 2016. "The Power of Fashion". Accessed in https://www.britishcouncil.org/research-policy-insight/insight-articles/power-fashion on January 272020.

Mbe, Vikas Shah. 2012. "The Role of Fashion in Human Culture". Accessed in https://thoughteconomics.com/the-role-of-fashion-in-human-culture/on January 272020. 